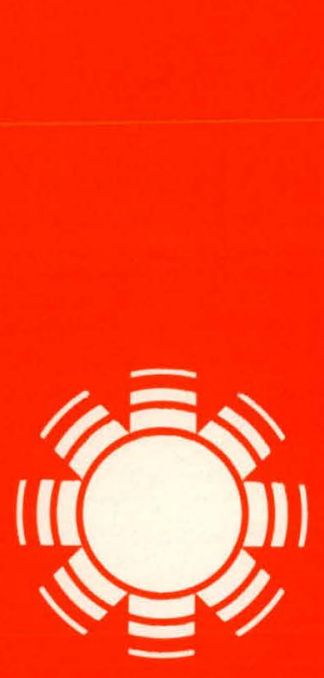

\title{
SERI Laser Scanner
} System

Richard 4. Matson

\section{Theodore W. Cannon}

\section{Solar Energy Research Institute}

A Division of Midwest Research Institute

1617 Cole Boulevard

Golden, Colorado 80401

Operated for the

U.S. Department of Energy under Contract No. EG-77-C-01-4042 


\section{DISCLAIMER}

This report was prepared as an account of work sponsored by an agency of the United States Government. Neither the United States Government nor any agency Thereof, nor any of their employees, makes any warranty, express or implied, or assumes any legal liability or responsibility for the accuracy, completeness, or usefulness of any information, apparatus, product, or process disclosed, or represents that its use would not infringe privately owned rights. Reference herein to any specific commercial product, process, or service by trade name, trademark, manufacturer, or otherwise does not necessarily constitute or imply its endorsement, recommendation, or favoring by the United States Government or any agency thereof. The views and opinions of authors expressed herein do not necessarily state or reflect those of the United States Government or any agency thereof. 


\section{DISCLAIMER}

Portions of this document may be illegible in electronic image products. Images are produced from the best available original document. 
Printed in the United States of America Available from:

National Technical Information Service

U.S. Department of Commerce

5285 Port Royal Road

Springfield, VA 22161

Price:

Microfiche $\$ 3.00$

Printed Copy $\$ 4.00$

\section{NOTICE}

This report was prepared as an account of work sponsored by the United States Government. Neither the United States nor the United States Department of Energy, nor any of their employees, nor any of their contractors, subcontractors, or their employees, makes any warranty, express or implied, or assumes any legal liability or responsibility for the accuracy, completeness or usefulness of any information, apparatus, product or process disclosed, or represents that its use would not infringe privately owned rights. 


\section{SERI'RR-612-733 \\ UC CATEGORY: UC -63}

\section{SERI LASER SCANNER SYSTEM}

RICHARD J . MATSON

THEODORE W. CANNON

OCTOBER 1980

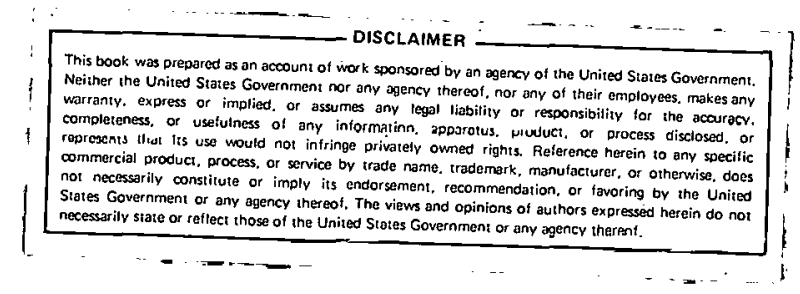

Prepared Under TASK Nu. 3825.10

\section{Solar Energy Research Institute}

A Division of Midwest Research Institute

1617 Cole Boulevard

Golden, Colorado 80401

Prepared for the

U.S. Department of Energy

Contract No. EG-77-C-01-4042 
THIS PAGE

\section{WAS INTENTIONALLY \\ LEFT BLANK}




\section{FOREWORD}

The Laser Scanner System (LSS) designed by the Solar Energy Research Institute (SERI) is patterned after the LSS at the National Bureau of Standards (NBS) in Gaithersburg, Maryland. The NBS Special Publication 400-24, "A Laser Scanner for Semiconductor Devices" by D. E. Sawyer and D. W. Berning, fully describes the purpose, principles of operation, and construction of the NBS LSS. This report describes the SERI LSS, its components, their function and operation, and how these differ from those described in the NBS publication. This report assumes reader familiarity with the NBS report and proceeds by specifying the significant modifications to the NBS system introduced by SERI. From these two reports the SERI LSS can be reproduced.

The development of the NBS laser scanner system was funded through an interagency agreement with NBS and the U.S. Department of Energy. SERI has the responsibility for technical monitoring of the development program. Because of a number of requests by photovoltaics researchers for NBS to provide LSS data on their samples, the LSS was recreated at.SERI in the Measurements and Evaluation Laboratory to provide the measurements.

NBS is developing a Reference Test Structure (RTS) based on theoretical calculations of the expected photoresponse of fault-free solar cells under examination by the laser scanner. The RTS will contain a solar cell with no intentional defects and adjacent test structures with defects. Completion of this effort will result in a quantitative measurement capability.

The authors wish to thank Clyde Carter and Harlan Weber of the SERI Measurement Research and Support Branch and Dave Sawyer and Herbert Kessler of NBS for their invaluable assistance in the design and construction of the SERI LSS.

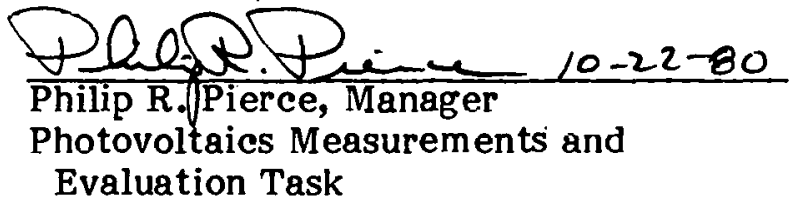

Approved for

SOLAR ENERGY RESEARCH INSTITUTE
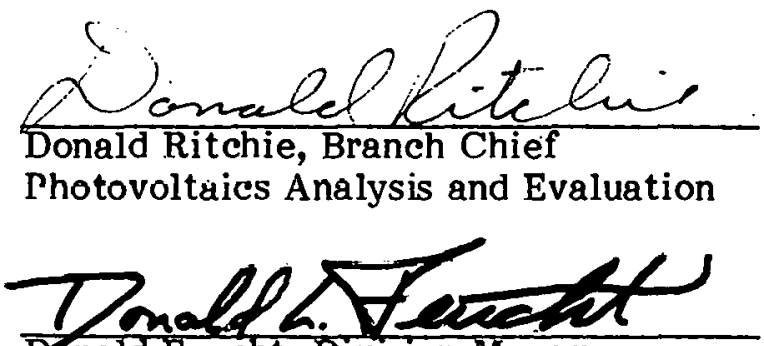

Donald Feucht, Division Manager

Photovoltaics Division 
THIS PAGE

\section{WAS INTENTIONALLY LEFT BLANK}


SEP

RR-733

SUMMARY

A Laser Scanner System (LSS) produces a photoresponse map and can be used for the nondestructive detection of nonuniformities in the photoresponse of a semiconductor device. At SERI the photoresponse maps are used to identify solar cell faults including microcracks, metallization breaks, regions of poor contact between metallization and the underlying emitter surface, and variations in emitter sheet resistance. The SERI LSS is patterned after the LSS unit documented in the NBS Special Publication 400-24, "A Laser Scanner for Semiconductor Devices" by D. E. Sawyer and D. W. Berning. Assuming reader familiarity with the above publication, the present report proceeds by specifying the modifications introduced by SERI with the intention that the two reports can be used to reproduce the SERI LSS. This report reviews the optical and electronic systems, briefly discussing the significant items of each. The most notable difference between the two systems is the SERI substitution of commercially available state-of-the-art moduar electronics for the discrete component circuitry used in the NBS LSS.

v 


\section{THIS PAGE}

\section{WAS INTENTIONALLY \\ LEFT BLANK}




\section{TABLE OF CONTENTS}

\section{Page}

1.0 Introduction $\ldots \ldots \ldots \ldots \ldots \ldots \ldots \ldots \ldots \ldots \ldots \ldots \ldots \ldots \ldots \ldots \ldots \ldots \ldots \ldots$

2.0 Design and Operation $\ldots \ldots \ldots \ldots \ldots \ldots \ldots \ldots \ldots \ldots \ldots \ldots \ldots \ldots \ldots \ldots \ldots$

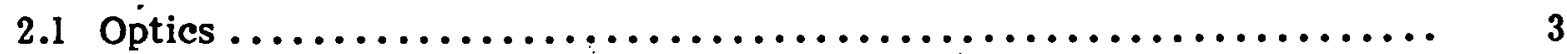

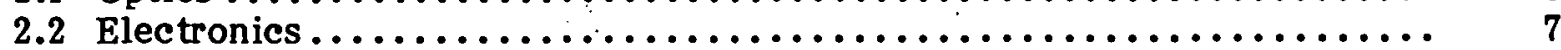

3.0 Future Modifications $\ldots \ldots \ldots \ldots \ldots \ldots \ldots \ldots \ldots \ldots \ldots \ldots \ldots \ldots \ldots \ldots \ldots \ldots \ldots, 18$ 


\section{THIS PAGE}

\section{WAS INTENTIONALLY LEFT BLANK}




\section{LIST OF FIGURES}

$\underline{\text { Page }}$

1 The Light and Signal Paths of the LSS. ..................... 3

2 (a) Laser Scanner Support Frame............................... 4

(b) Laser Scanner Assembly. ............................. 5

3 Reflected Light Detector Circuit. ........................ 7

4 Block Diagram of the Basic Electronic Components and Their Inter connections. ................................ 10

5 Phase Shift Circuit. $\ldots \ldots \ldots \ldots \ldots \ldots \ldots \ldots \ldots \ldots \ldots \ldots \ldots \ldots \ldots \ldots \ldots \ldots \ldots \ldots$

6 Blanking Circuit. ................................. 13

7 Magnification Circuit. $\ldots \ldots \ldots \ldots \ldots \ldots \ldots \ldots \ldots \ldots \ldots \ldots \ldots \ldots \ldots \ldots \ldots \ldots$

8 Impedance Matching Circuit. $\ldots \ldots \ldots \ldots \ldots \ldots \ldots \ldots \ldots \ldots \ldots \ldots \ldots \ldots \ldots$

$9 \quad$ Signal Mixing Circuit $\ldots \ldots \ldots \ldots \ldots \ldots \ldots \ldots \ldots \ldots \ldots \ldots \ldots \ldots \ldots \ldots \ldots \ldots \ldots \ldots$

\section{LST OP TABLES}

1 Comparison of NBS and SERI Laser Scanner Systems Electronics. 


\section{SECTION 1.0}

\section{INTRODUCTION}

The principle of operation of a laser scanner is to raster a laser beam over the surface of a photosensitive device while recording on a CRT display the photoresponse as a function of the laser beam's position. This results in a spatial map of the photoresponse current. The photoresponse maps are used to identify cell faults including cracks, metallization breaks, regions of poor contact between metallization and the underlying emitter surface, and variations in emitter sheet resistance. Additionally, light reflected from the surface of the device is detected and used to produce a reflected-light image of the area being scanned. This image is used to relate topographical features to spatial variations in the photoresponse. Both the photoresponse signal and the reflected light signal can be presented in either a $\mathrm{Y}$ (deflection) or $\mathrm{Z}$ (intensity) modulation mode on the monitors. These signals in turn can be superimposed for correlation purposes.

In this report we review the LSS optics and electronics subsystems and briefly discuss the significant items of each. 


\section{SEPI}




\section{SECTION 2.0}

\section{DESIGN AND OPERATION}

\subsection{OPTICS}

A diagram of the light and signal paths of the laser scanner system is shown in Fig. 1. Figures 2(a) and (b) are drawings of the frame and assembly, respectively, that support the optical component. The system uses two HeNe lasers: a 5-mW unit with $\lambda=$ $0.633 \mathrm{~m}$ visible light for photoresponse mapping, and a $1-\mathrm{mW}$ unit with $\lambda=1.15 \mu \mathrm{m}$ near-infrared light for back-contact mapping. The light source can be selected by moving mirror $M_{1}$ (Fig. 1) along a keyed rod (Fig. 2(b), parts 3 and 4). This configuration differs from that of the NBS system in that the NBS unit has a laser on either side of the support frame and thereby employs an additional mirror surface in the optical path (see Figs. 1 and C-1 of the NBS report). Elimination of this extra optical surface simplifies the system.

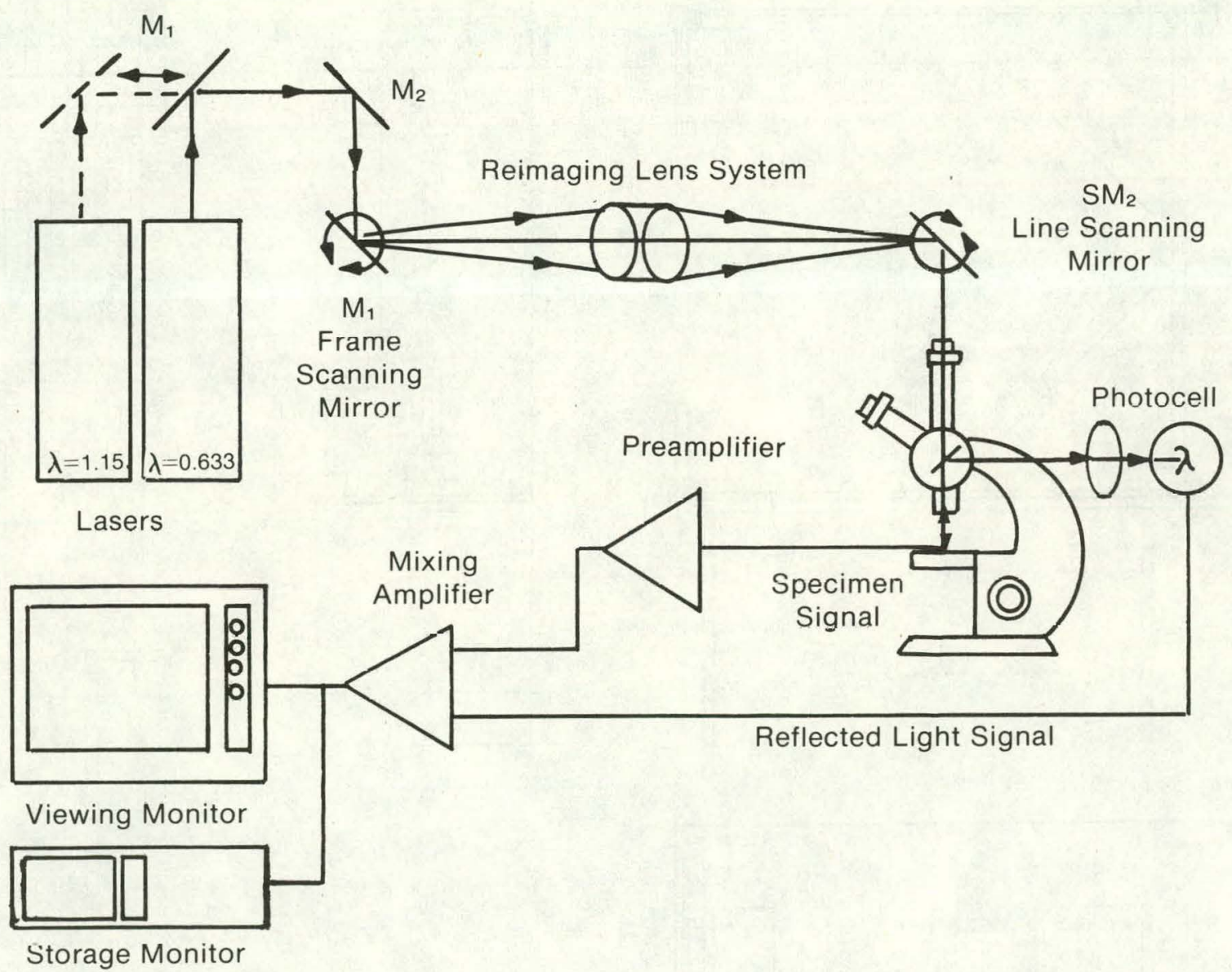

Figure 1. The Light and Signal Paths of the Laser Scanner System 


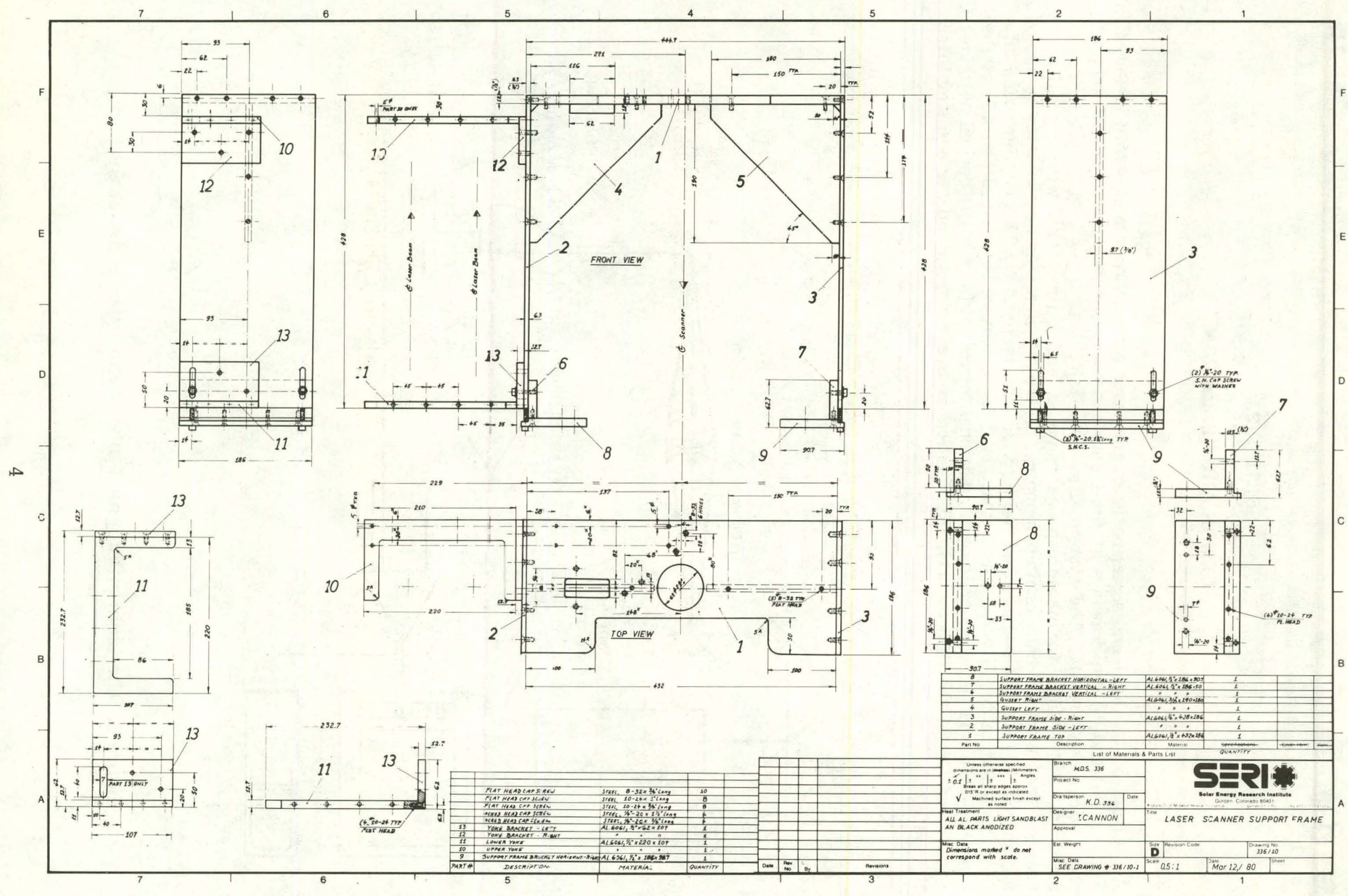

Figure 2. (a) Laser Scanner Support Frame 


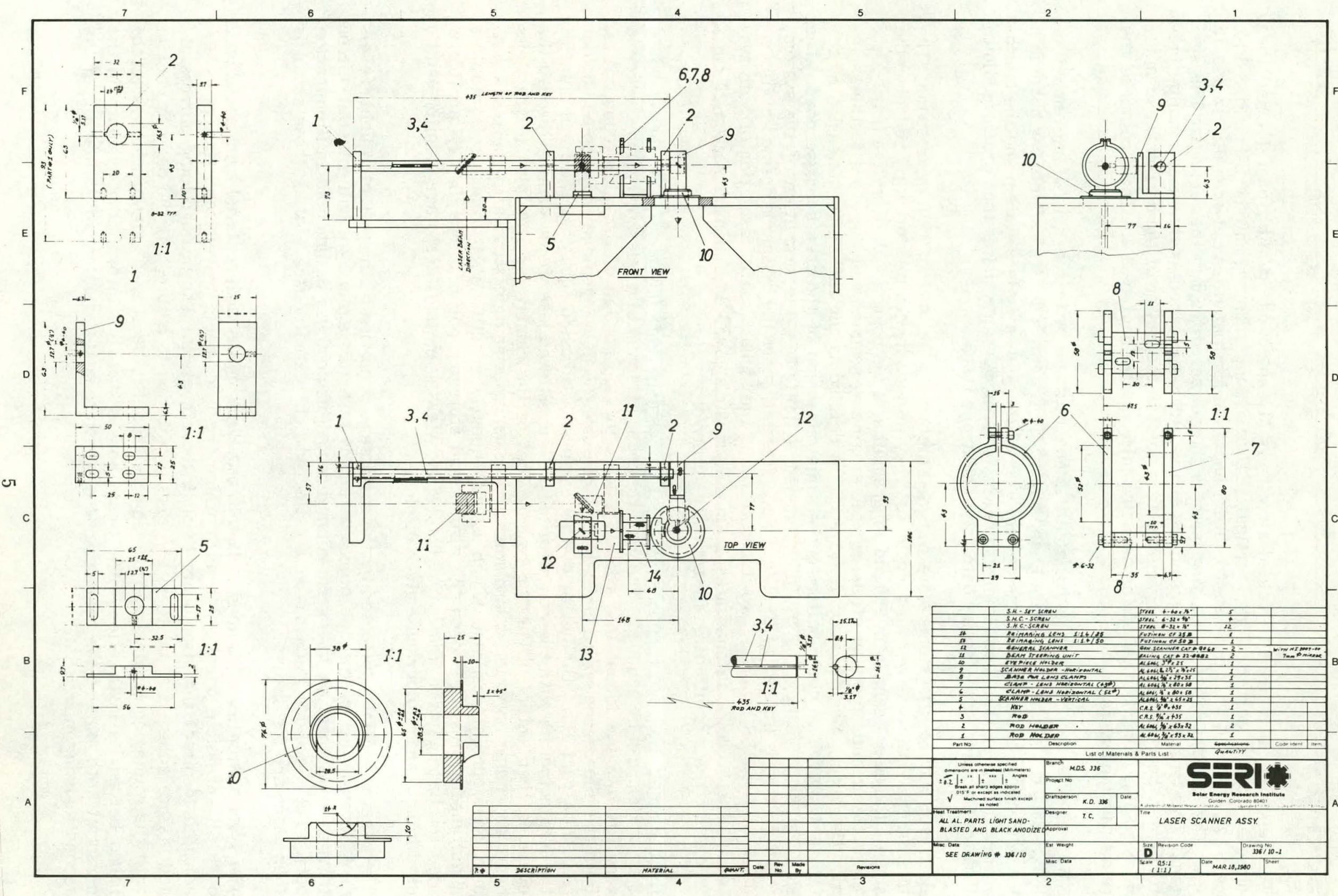

Figure 2. (b) Laser Scanner Assembly 
The selected laser beam is folded at mirrors $M_{1}$ and $M_{2}$ [Fig. 2(b), part 11] and then directed to the center of the vertical (Y), or frame, scanning mirror SM [Fig. 2(b), part 12]. Mirror $\mathrm{SM}_{1}$ deflects the beam back and forth at rates between $0.1 \mathrm{~Hz}$ and 10 $\mathrm{Hz}$. The one-dimensional scanning beam is then directed through the reimaging lens system. This lens system (see Appendix B of the NBS report) focuses the laser beam deflection from the vertical scanning mirror to a point in the center of the horizontal scanning mirror $\mathrm{SM}_{2}$. The centers of the scanning mirrors are located at the focal points of the reimaging lens system.

$\mathrm{SM}_{1}$ deflects the beam in a horizontal plane coplanar with the axis of movement of $\mathrm{SM}_{2}$ : $\mathrm{SM}_{2}$ is mounted horizontally and when $\mathrm{SM}_{1}$ is centered, $\mathrm{SM}_{2}$ deflects the beam in a vertical plane coplanar with the optical axes of the reimaging lens system and the microscope. This results in a two-dimensional raster or area scan which is then projected down through the microscope optics onto the microscope stage.

Both NBS and SERI systems were designed around the Zeiss Model WL microscope. The microscope optics serve two functions. 'I'hey provide higher resolution by reducing the size of the laser beam from $900 \mu \mathrm{m}$ to as small as $4 \mu \mathrm{m}$ using a $40 \mathrm{X}$ objective lens. Also, the optics reduce the size of the sample area being scanned and therefore further magnify the area. Magnification for the LSS is defined as the ratio of a dimension of the image displayed on the monitor to the same dimension of the area being scanned. The smallest area that can be usefully scanned is limited by the resolution of the system, which in turn is limited by the beam size. Resolution for the system is defined in Appendix F of the NBS report. Two micrometres is the highest useful resolution of both systems. Therefore, a scanned area $2 \mu \mathrm{m}$ on a side displayed on a monitor screen $20 \mathrm{~cm} \mathrm{x}$ $25 \mathrm{~cm}$ yields a magnification factor on the order of $10^{5}$.

By replacing the microscope optics with a camera lens ( $55 \mathrm{~mm} / \mathrm{f} 1.4$ ), areas up to $8 \mathrm{~cm} \times 8 \mathrm{~cm}$ can be scanned. The camera lens is attached to a telescoping lube, which in turn fits into the mount that normally holds the top portion of the microscope optics. Both the microscope optics and camera optics use the Zeiss eyepiece and eyepiece holder [Fig. 2(b), part 10]. The height of the eyepiece is adjusted such that the focal point of the lens coincides with the center of $\mathrm{SM}_{2}$. The rastered laser beam coming through the eyepiece then enters either the camera lens or the camera tube opening in the Zeiss head, depending on which is in place. The scanning laser light stimulates the test specimen photocurrent response which is subsequently conditioned by the electronics for simultaneous presentation on the display and storage monitors. The display monitor is used for further magnification of details and viewing ease. The storage monitor can be used to hold and photograph a given display.

The beam is partially reflected by the specimen. A portion of the reflected light travels back through the microscope objective and is reflected again by a half-silvered mirror through a side port on to a germanium diode. This port was designed as an illumination port. The Ge diode functions as a reflected light detector (see Fig. 3) whose signal is then processed for display.

The system is optically aligned in two steps. First, masks with centered holes are placed over all accessible openings through which the laser beam travels, and the optics are adjusted to direct the laser beam through these centers. The beam folding mirrors $\mathrm{M}_{1}$ and $\mathrm{M}_{2}$ are adjusted about their two axes of rotation to ensure that the beam is coaxial with the reimaging lens axis. This requires that $\mathrm{SM}_{1}$ be at a $45^{\circ}$ angle, which is established before its installation. The beam now is directed through the openings in the masks at both ends of the reimaging lens system and is deflected off the center of the second scanning mirror $\mathrm{SM}_{2}$. 


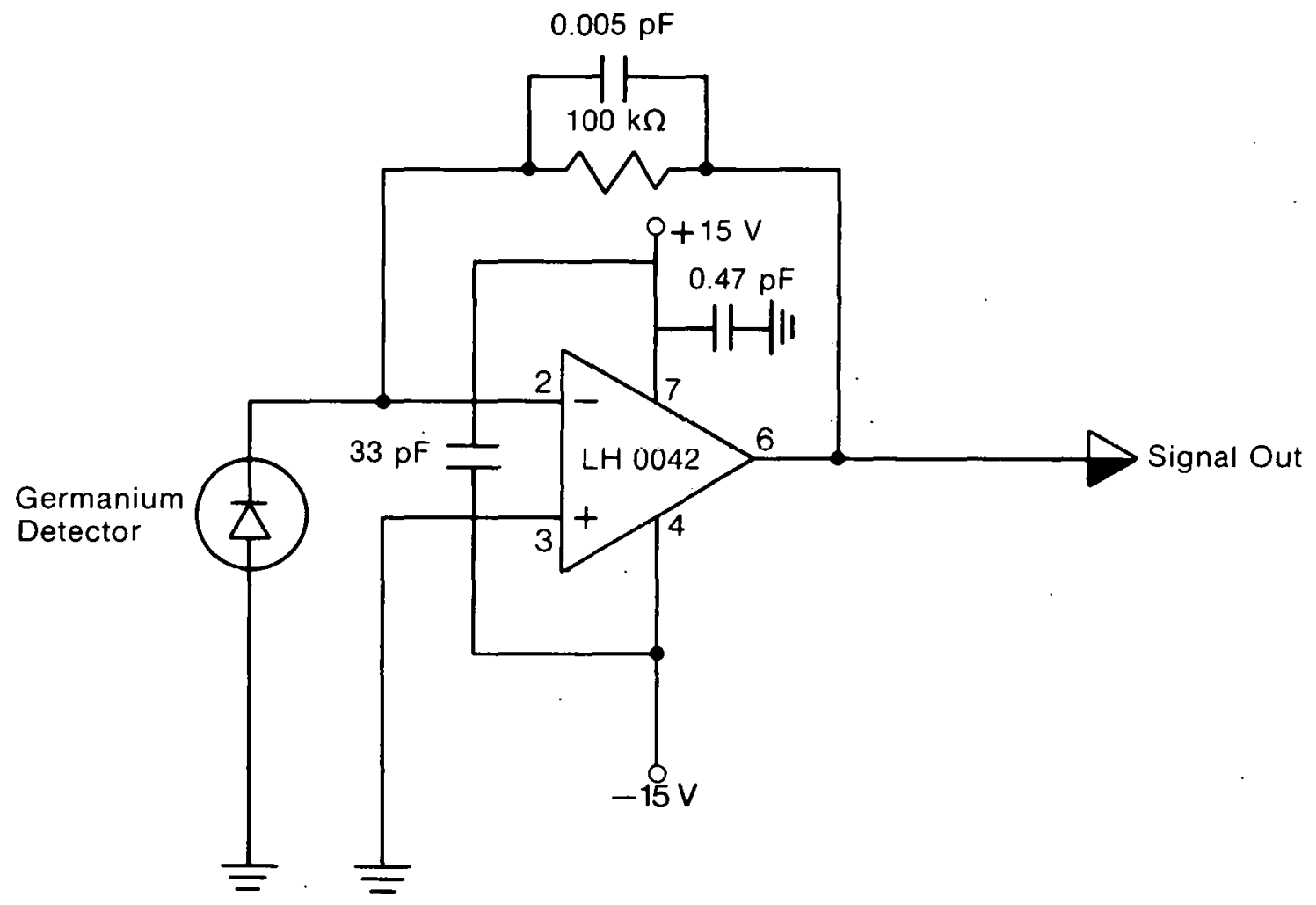

Figure 3. Reflected Light Detector Circuit

With $\mathrm{SM}_{2}$ at a $45^{\circ}$ angle, the beam should be nearly coaxial with the optical axis of the microscope. Three adjustment screws in the base of the laser scanner support frame are used to determine the height and angles of the support frame with respect to the microscope base upon which the support frame is mounted. The locations for these adjustment screws are shown in parts 8 and 9 in Fig. 2(a). The two openings at each of the three locations are for a leveling serew und a screw to secure the adjusted level. Adjustment of these screws aligns the laser beam with the microscope optical axis.

The second step refines the results of the first step. With a flat mirror on the microscope stage, the system is finely adjusted to ensure that the beam autocollimates. The system is aligned when the reflection patterns back at the head of the laser are symmetric.

\subsection{RLECTRONICS}

The most significant difference between the SERI and the NBS laser scanner systems is the SERI substitution of commercially available modular electronics for the corresponding discrete component circuitry. This approach allows a timelier fabrication of the system without sacrificing versatility. Table 1 compares the SERI and NBS approaches. The discussions in this section, as well as Table 1 , are keyed to the numbers in Fig. 4, which is a block diagram of the electronic components making up the LSS. 
Table 1. COMPARISON JF NBS AND SERI LASER SCANNER SYSTEMS ELECTRONICS

\begin{tabular}{|c|c|c|c|c|c|c|}
\hline Number & Unit & Function. & Controls Used with Scanner & NBS & SERI & Comments \\
\hline 1 & Function generator & $\begin{array}{l}\text { Generates sinusoidal } \\
\text { waveform for } \\
\text { horizontal scan. }\end{array}$ & $\begin{array}{l}\text { Frequency, frequency } \\
\text { multiplier, "unction, } \\
\text { a nplitude }\end{array}$ & $\begin{array}{l}\text { Wavetek functior } \\
\text { generator }\end{array}$ & $\begin{array}{l}\text { Tektrorix F G 501 } \\
\text { l-MHz function generator }\end{array}$ & - \\
\hline 2 & Function generator & $\begin{array}{l}\text { Generates sawtooth } \\
\text { waveform for } \\
\text { vertical scan. }\end{array}$ & $\begin{array}{l}\text { Frequency, frequency } \\
\text { multiplier, Iunction, } \\
\text { amplitude }\end{array}$ & $\begin{array}{l}\text { Wavetek function: } \\
\text { generator }\end{array}$ & $\begin{array}{l}\text { Tektrogix FG } 501 \\
\text { l-MHz function generator }\end{array}$ & - \\
\hline 3 & Power amplifier & $\begin{array}{l}\text { Provides power to } \\
\text { drive scanner. } \\
\text { Incorporates mag- } \\
\text { nifier circuit. }\end{array}$ & $\begin{array}{l}\text { Zero, gain } \\
\text { Magnification }\end{array}$ & $\begin{array}{l}\text { General scanner } \\
\text { model AX } 200\end{array}$ & $\begin{array}{l}\text { Genera saanner } \\
\text { model AX } 200 \text { with } \\
\text { magnif:er circuit } \\
\text { added at SERI }\end{array}$ & $\begin{array}{l}\text { NBS unit has separate magnifier } \\
\text { controls; see Fig. E-5, } \\
\text { NBS } 400-24 \text {. }\end{array}$ \\
\hline 4 & Scanners & $\begin{array}{l}\text { Deflect laser beam } \\
\text { to provide raster } \\
\text { scan of sample. }\end{array}$ & None & $\begin{array}{l}\text { General scanner } \\
\text { model G-060 wit } \\
\text { model MI-1007-000 } \\
7 \text {-mm-diam eter } \\
\text { mirror }\end{array}$ & $\begin{array}{l}\text { General scanner } \\
\text { model } \mathrm{G}-060 \text { with } \\
\text { model MI } 1007-00, \\
7-\mathrm{mm} \text {-diameter } \\
\text { mirror }\end{array}$ & - \\
\hline 5 & Phase shifter & $\begin{array}{l}\text { Adjusts phase of } \\
\text { horizontal drive } \\
\text { to monitor } \\
\text { in relation to the } \\
\text { lag in mechanical } \\
\text { phase of mirror. }\end{array}$ & Fhase & $\begin{array}{l}\text { NBS designed and } \\
\text { fabricated circu:t }\end{array}$ & $\begin{array}{l}\text { SERI-cesigned and } \\
\text { fabrice te J circuit } \\
\text { diagran, Fig. } 4\end{array}$ & $\begin{array}{l}\text { SERI phase shift circuit is } \\
\text { located in mixer chassis. }\end{array}$ \\
\hline 6 & Signal ampifier & $\begin{array}{l}\text { Amplifies X-axis } \\
\text { signal to obtain } \\
\text { app ropriate width of } \\
\text { display on monitors. }\end{array}$ & Gain & $\begin{array}{l}\text { NBS design end } \\
\text { fabrication; } \\
\text { see Fig. F-4 of } \\
\text { NBS } 400-24\end{array}$ & $\begin{array}{l}\text { Textrcnir: AM } 502 \\
\text { different.al empli- } \\
\text { fier (u:sec single } \\
\text { ended) }\end{array}$ & $\begin{array}{l}\text { Set filter for maximum } \\
\text { bandwith, use AC coupling. } \\
\text { Exchange input terminals to } \\
\text { effect } 180 \text {-degree phase } \\
\text { change in } X \text {-axis scan. }\end{array}$ \\
\hline 7 & Signal amplifier & $\begin{array}{l}\text { Amplifies cell } \\
\text { signal to provide } \\
\text { appropriate signal } \\
\text { level in relation to } \\
\text { Y-axis drive signal } \\
\text { to monitors. Provides } \\
\text { fil tering tc remove } \\
\text { excess noise from } \\
\text { cell signal. }\end{array}$ & $\begin{array}{l}\text { Gain, } \\
\text { LF-3 dB pcint, } \\
\text { HF-3 dB point, }\end{array}$ & $\begin{array}{l}\text { NBS design and } \\
\text { fabrication; } \\
\text { see Fig. E-4 of } \\
\text { NBS 400-24 }\end{array}$ & $\begin{array}{l}\text { Tektraniz A M } 502 \\
\text { differential } \\
\text { amplifier } \\
\text { (used single ended) }\end{array}$ & $\begin{array}{l}\text { Set filters to reduce noise level } \\
\text { of signal, use AC coupling. } \\
\text { Exchange input terminals to } \\
\text { effect reversal in direction } \\
\text { of photoresponse signal. }\end{array}$ \\
\hline 8 & Blanking circuit & $\begin{array}{l}\text { Provides vertical anc } \\
\text { horizontal blankirg } \\
\text { of monitors, pro- } \\
\text { vides single sean } \\
\text { on com mand. Bires } \\
\text { Z-axis modulation } \\
\text { with blanking. }\end{array}$ & $\begin{array}{l}\text { 3lanking enable-disable, } \\
\text { single-con-inuous sweep. } \\
\text { single-sweep trigger }\end{array}$ & $\begin{array}{l}\text { Blanking signals } \\
\text { provided by } \\
\text { function genera :ors; } \\
\text { see Figs. } 2 \text { and } \\
\text { E-1, NBS } 400-2 a\end{array}$ & $\begin{array}{l}\text { SERI design and } \\
\text { fabrization: circuit } \\
\text { diagrair, Fig. } 5\end{array}$ & - \\
\hline
\end{tabular}


Table 1. COMPARISON OF NBS AND SERI LASER SCANNER SYSTEMS ELECTRONICS (concluded)

\begin{tabular}{|c|c|c|c|c|c|c|}
\hline Number & Unit & Function & Controls Used with Scanner & NBS & SERI & Comments \\
\hline 9 & 30-dB attenuator & $\begin{array}{l}\text { Reduces } Y \text {-axis scan } \\
\text { signa! to appropri- } \\
\text { ate level for mixer. }\end{array}$ & None & $\begin{array}{l}\text { Separate amplitude } \\
\text { control for each } \\
\text { channel of mixer, } \\
\text { see Fig. } 3 \text {, } \\
\text { NBS } 400-24\end{array}$ & $\begin{array}{l}\text { Standard BNC } \\
\text { attenuator }\end{array}$ & - \\
\hline 10 & Signal mixer & $\begin{array}{l}\text { Provides composite } \\
\text { signal from up to } \\
\text { three mixed channels. } \\
\text { Provides for transfer } \\
\text { of channel } 3 \text { signal } \\
\text { between mixer ( } Y \text {-axis } \\
\text { modulation) and } \\
\text { blanking circuit } \\
\text { (Z-axis modulation). }\end{array}$ & $\begin{array}{l}\text { On-off switch ior each } \\
\text { channel, Y to } Z \text { transfer, } \\
\text { modulation transfer, } \\
\text { 10X-100X gain switch }\end{array}$ & $\begin{array}{l}\text { NBS fabrication; } \\
\text { see Fig. E-2, } \\
\text { NBS 400-24 }\end{array}$ & $\begin{array}{l}\text { SERI design and } \\
\text { fabric.gtion; } \\
\text { see Fig. } 9\end{array}$ & - \\
\hline 11 & 14-inch mon:tor & $\begin{array}{l}\text { Large display monitor } \\
\text { for viewing scan } \\
\text { information }\end{array}$ & $\begin{array}{l}X-\text { position, } \\
Y-\text { position, } \\
\text { intensity }\end{array}$ & $\begin{array}{l}\text { Hewlett-Packard } \\
\text { model } 1300 \mathrm{~A} \\
\mathrm{X}-\mathrm{Y} \text { monitor }\end{array}$ & $\begin{array}{l}\text { Hewlett-Packard } \\
\text { model } 1304 \mathrm{~A} \\
X-Y \text { m.onitor }\end{array}$ & - \\
\hline 12 & $\begin{array}{l}\text { 4-inch storage } \\
\text { monitor }\end{array}$ & $\begin{array}{l}\text { Stores sean in- } \\
\text { formation for } \\
\text { viewing or } \\
\text { photography. }\end{array}$ & $\begin{array}{l}X \text { - position, } \\
Y \text { - position, } \\
\text { intensity }\end{array}$ & Not used & $\begin{array}{l}\text { Teixtranix model } \\
607 \text { A storage monitor }\end{array}$ & - \\
\hline 13 & Oscilloscope & $\begin{array}{l}\text { Displays cell } \\
\text { signal. Is useful } \\
\text { for determining } \\
\text { proper optical and } \\
\text { electrical adjustment } \\
\text { of scenner. }\end{array}$ & $\begin{array}{l}\text { Normal oscilloscope } \\
\text { controls }\end{array}$ & & Textronix model SC501 & - \\
\hline 14 & Voltage supply & $\begin{array}{l}\text { Provides bias current } \\
\text { to specimen. }\end{array}$ & + volts & $\begin{array}{l}\text { External } 0-\text { to } 20- \\
\text { volt supply }\end{array}$ & $\begin{array}{l}\text { Tektronix PS } 503 \\
\text { Dual Tracking Voltage } \\
\text { Supply }\end{array}$ & - \\
\hline 15 & $\begin{array}{l}\text { Digital } \\
\text { multimeter }\end{array}$ & $\begin{array}{l}\text { Monitors bias currer.t } \\
\text { applied to specimen. }\end{array}$ & $\begin{array}{l}\text { Normal multimeter } \\
\text { controls }\end{array}$ & $\begin{array}{l}\text { Voltmeter in- } \\
\text { corporated into } \\
\text { systems }\end{array}$ & $\begin{array}{l}\text { Tektrcnix DM 501A } \\
\text { Digital Multimeter }\end{array}$ & - \\
\hline 16 & $\begin{array}{l}\text { Impedance } \\
\text { matching circuit }\end{array}$ & $\begin{array}{l}\text { Matches low dynamic } \\
\text { resistance of cell to } \\
\text { input of signal } \\
\text { a mplifier. Provides } \\
\text { decoupling of bias } \\
\text { signal from signal } \\
\text { amplifier input. }\end{array}$ & None & None & $\begin{array}{l}\text { Fabricgted in-house; } \\
\text { NBS design }\end{array}$ & $\begin{array}{l}\text { SERI } 43000 \mu \mathrm{F} \text { capacitor } \\
\text { polarity is unidirectional } \\
\text { so that only positive voltage } \\
\text { may be applied to the bias } \\
\text { voltage terminal of impedance } \\
\text { matching circuit. Connections } \\
\text { to the specimen cell may be } \\
\text { reversed to change bias polarity. }\end{array}$ \\
\hline
\end{tabular}




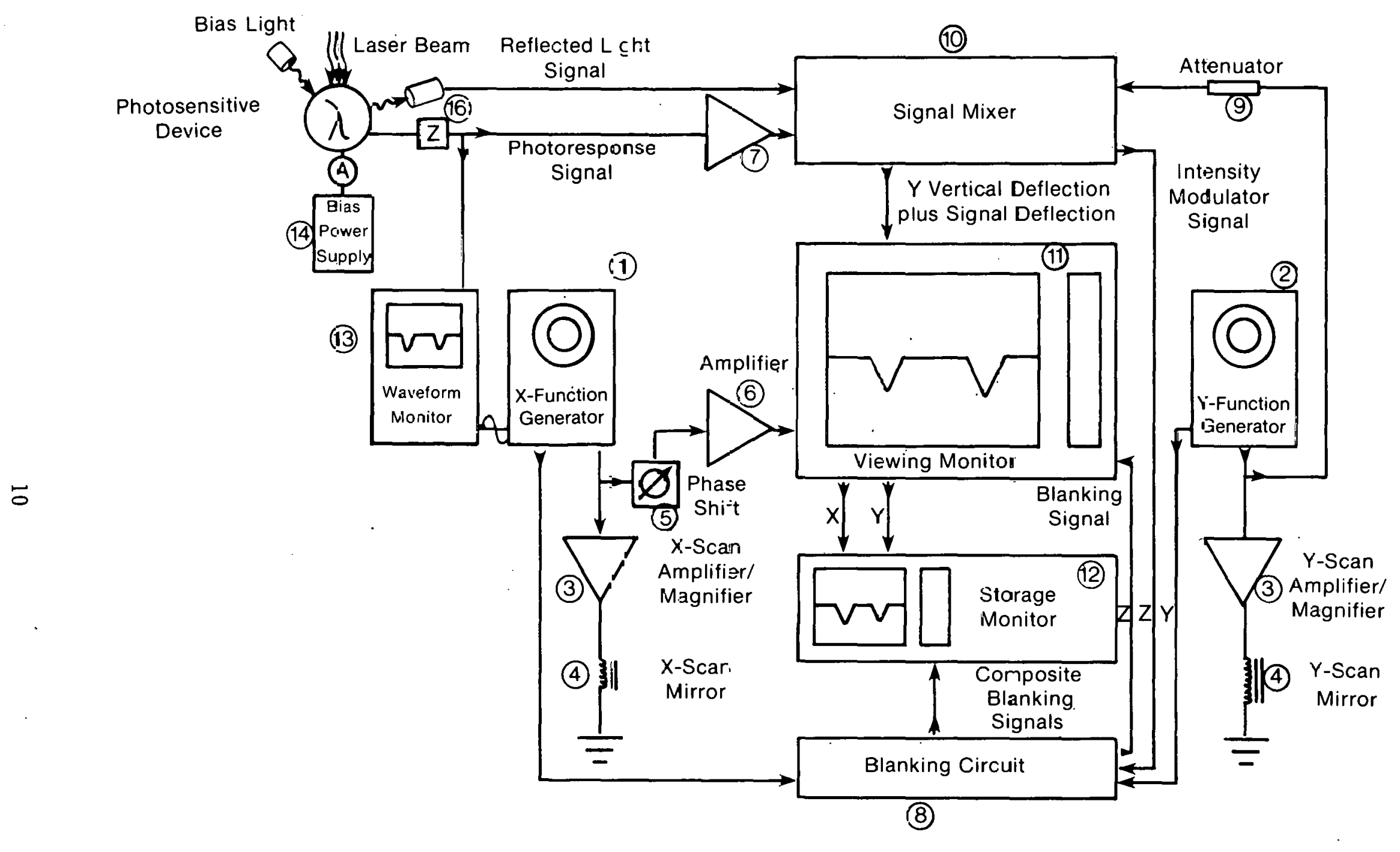

Figure 4. Block Diagram of the Basic Electronic Components and Their Interconnections 
The X-function generator (component 1) produces a sinusoidal waveform for the monitors $(11,12)$ and a trigger pulse for the blanking circuit $(8)$, the waveform monitor (13), and the $\mathrm{X}$, or line, scanner drive amplifier (3) and mirror (4). The function generator rate is set normally anywhere from $100 \mathrm{~Hz}$ to $1200 \mathrm{~Hz}$. The higher the ratio of the frame to line scan rate, the higher is the resolution. However, electronic ringing will be noticed at the higher scan rates and also at lower magnifications. This ringing shows up in the signal immediately after the crossing of a metallization by the laser beam. It is caused by the sharp pulse rise time which excites higher-order Fourier frequency components. The faster the beam moves from a light insensitive area to a sensitive area, the sharper is the rise time. Thus, the scan rate is determined by the response time of the device and the desired CRT resolution.

The $\mathrm{X}$-scan signal is fed to the horizontal drives of the monitors through an adjustable phase shift circuit (5) (see also Fig. 5) that compensates for the shift in the phase of the mirror position relative to the drive signal. Both the frequency and the amplitude of the drive on the mirror affect this phase relation. Phase shift circuitry is not required for the $\mathrm{Y}$-drive because the $\mathrm{Y}$, or frame, scanning rates are kept at much lower frequencies $(0.1 \mathrm{~Hz}$ to $10 \mathrm{~Hz})$. This phase-adjusted signal is then fed through an amplifier (6) to the horizontal drive of both monitors. The purpose of the amplifier is to adjust the area of the CRT displays covered by the signal. The gain on each monitor is adjusted such that an equal percentage of both screens is filled at any given setting of the amplifier (6).

Trigger pulses from both the horizontal and vertical function generators are fed into the blanking circuit (8) (see Fig. 6) to facilitate blanking on both return sweeps of the signal, thereby providing a clearer presentation of the data display. The X-function generator provides the frequency rate for the power amplifier (3) that drives the line scanner mirror. Both General Scanning Model 120 scan driver amplifiers have been modified by replacing the gain controls with magnification control circuitry (see Fig. 7). The modification includes a $15-\mathrm{V}$ power module required for the amplifiers.

Finally, the $\mathrm{X}$-function generator triggers an oscilloscope (13) that monitors the photoresponse signal coming directly out of the impedance-matching transformer (16, see Fig. 8). The oscilloscope is used for comparing signals before and after the various stages of conditioning.

The Y-function generator (2) generates a sawtooth or ramp waveform for (a) the blanking circuit (8), (b) the signal mixer (10), and (c) the $Y$ or frame scanner drive amplifier (3) and mirror (4). The vertical $(\mathrm{Y})$ drive is provided to both monitors through the signal mixer (10, see Fig. 9). The signal mixer provides a composite signal from up to three inputs; namely, the vertical sweep, the photocurrent response signal from the device, and the reflected light signal. The signal from the function generator requires 50- $\mathrm{dB}$ attenuation (9) because the signal level required for the $\mathrm{Y}$-scan amplifier is much larger than that required at the signal mixer input. In the amplitude modulation mode, the photoresponse signal and/or the reflected light signal is superimposed on the vertical deflection signal feed to the CRT' monitors. In the intensity modulation mode, the selected signal or signals from the device are fed through the signal mixer to the blanking circuit, which in turn controls the intensity level in the monitors.

Finally, the photoresponse device is often forward biased to enhance any electronic defects detected in the test sample's photoresponse. This is accomplished by either light biasing or electrical biasing of the test sample. Light biasing provides uniform biasing across the cell and has the advantages of aiding the mathematical modeling of the fault and being the only method of biasing devices, such as CdS, for which the principle of 


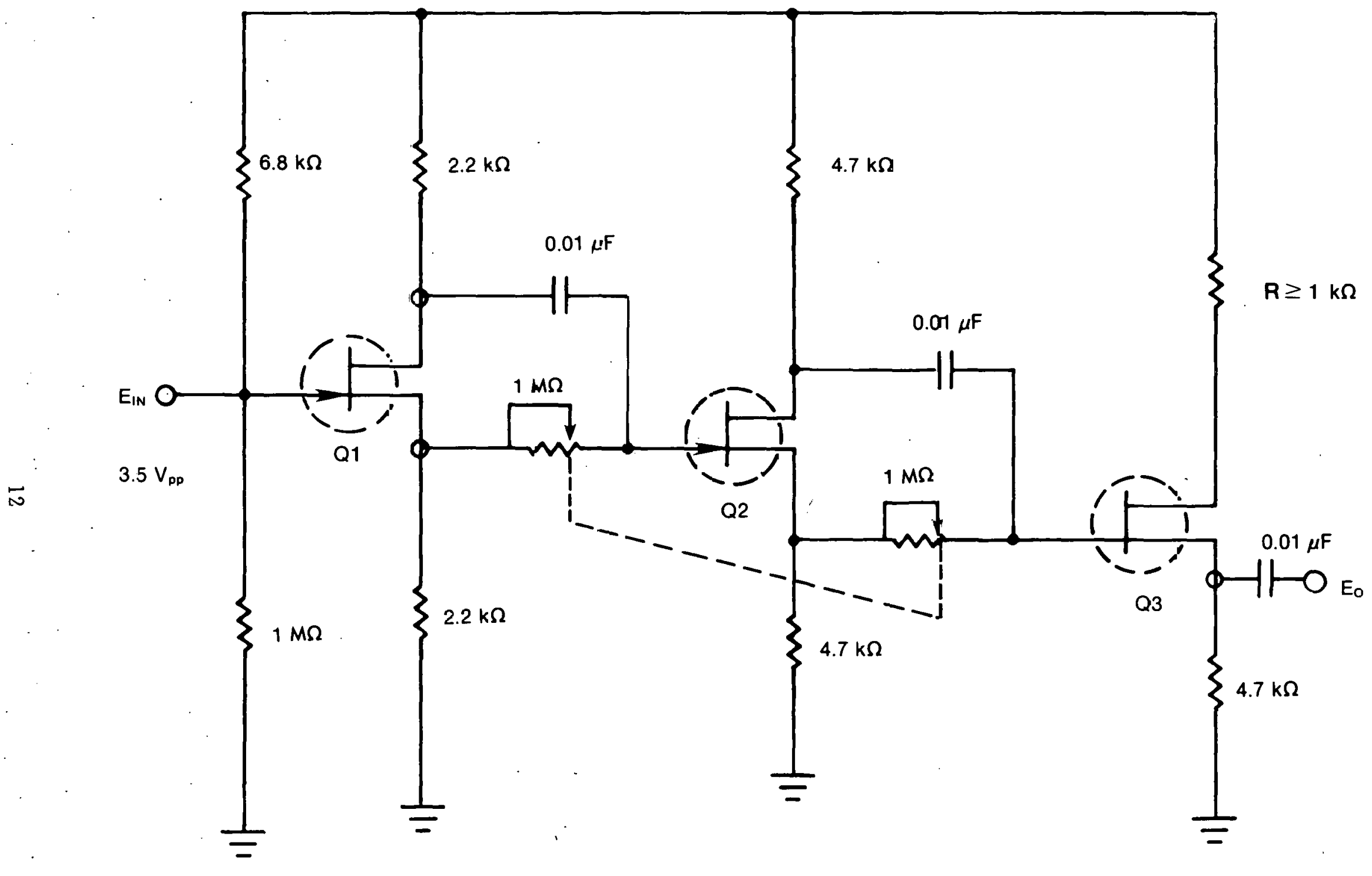

Figure 5. Phase Shift Circuit

Notes

( $)$ Q $\mathrm{Q} 1-\mathrm{Q} 3=2 \mathrm{~N} 4393$

(2) Resistors $1 / 4$ W, $5 \%$ except dual $1 \mathrm{M} \Omega$ Pot 


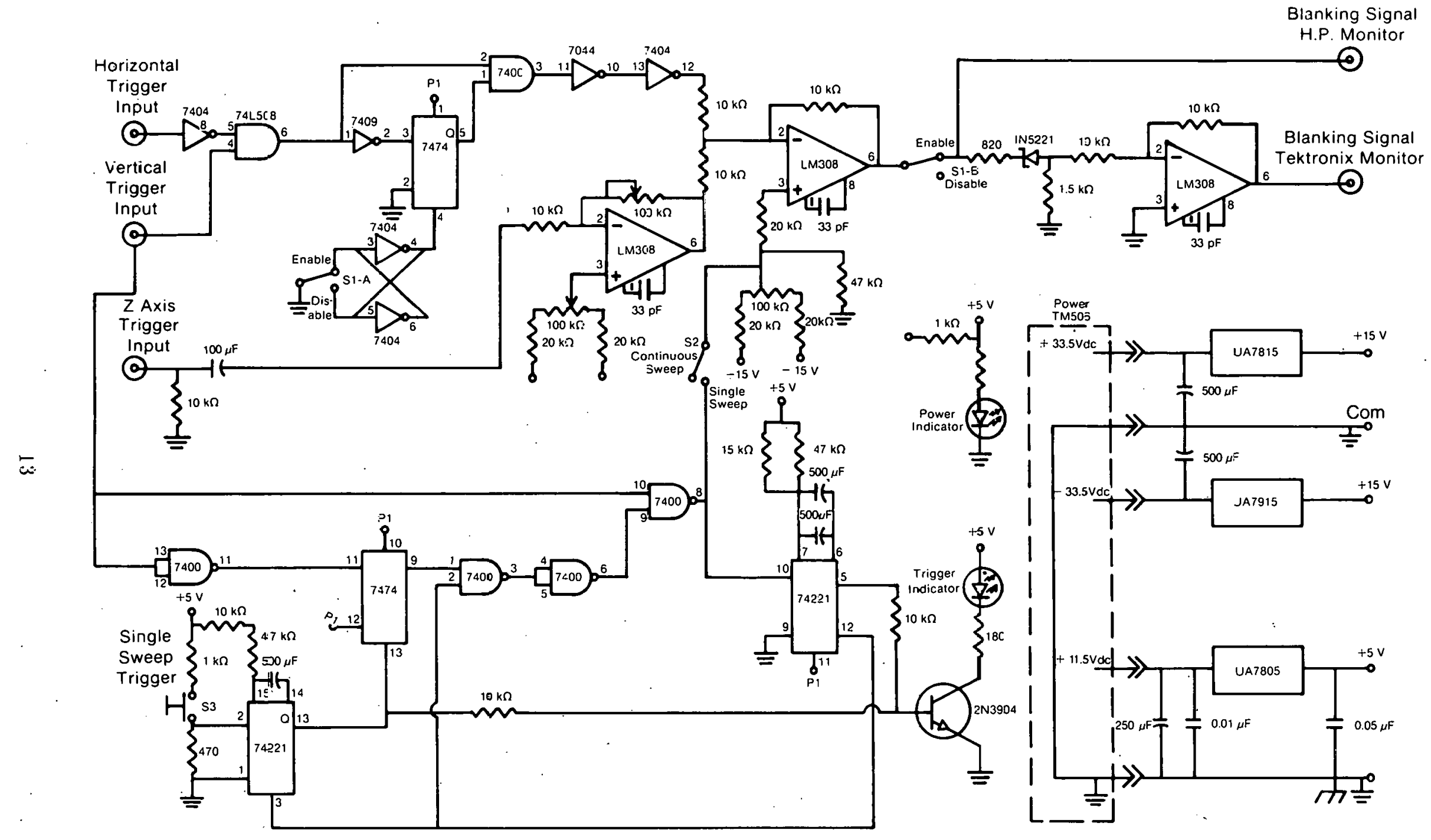

Figure 6. Blanking Circuit 

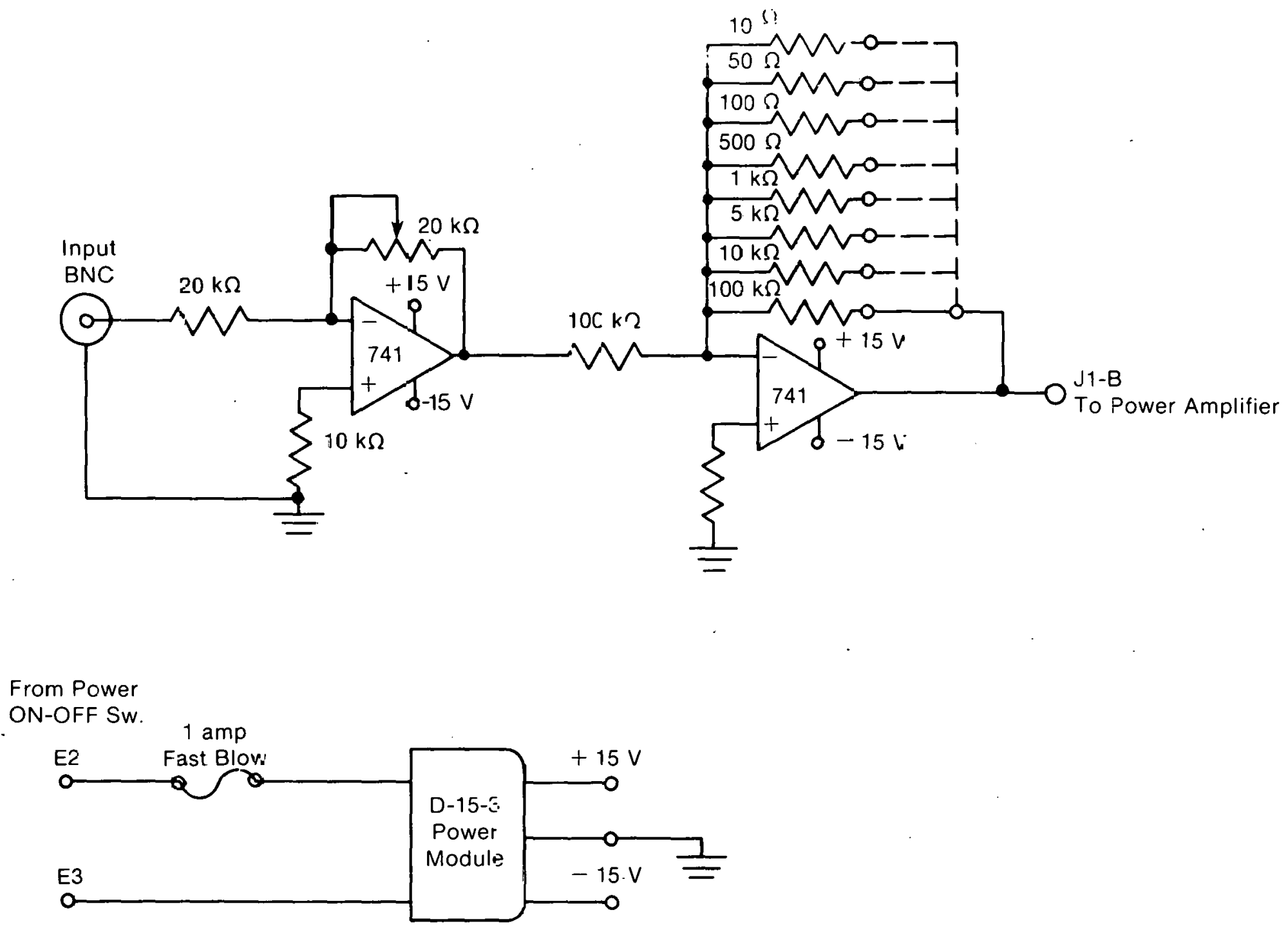

Figure 7. Magnification Circuit 


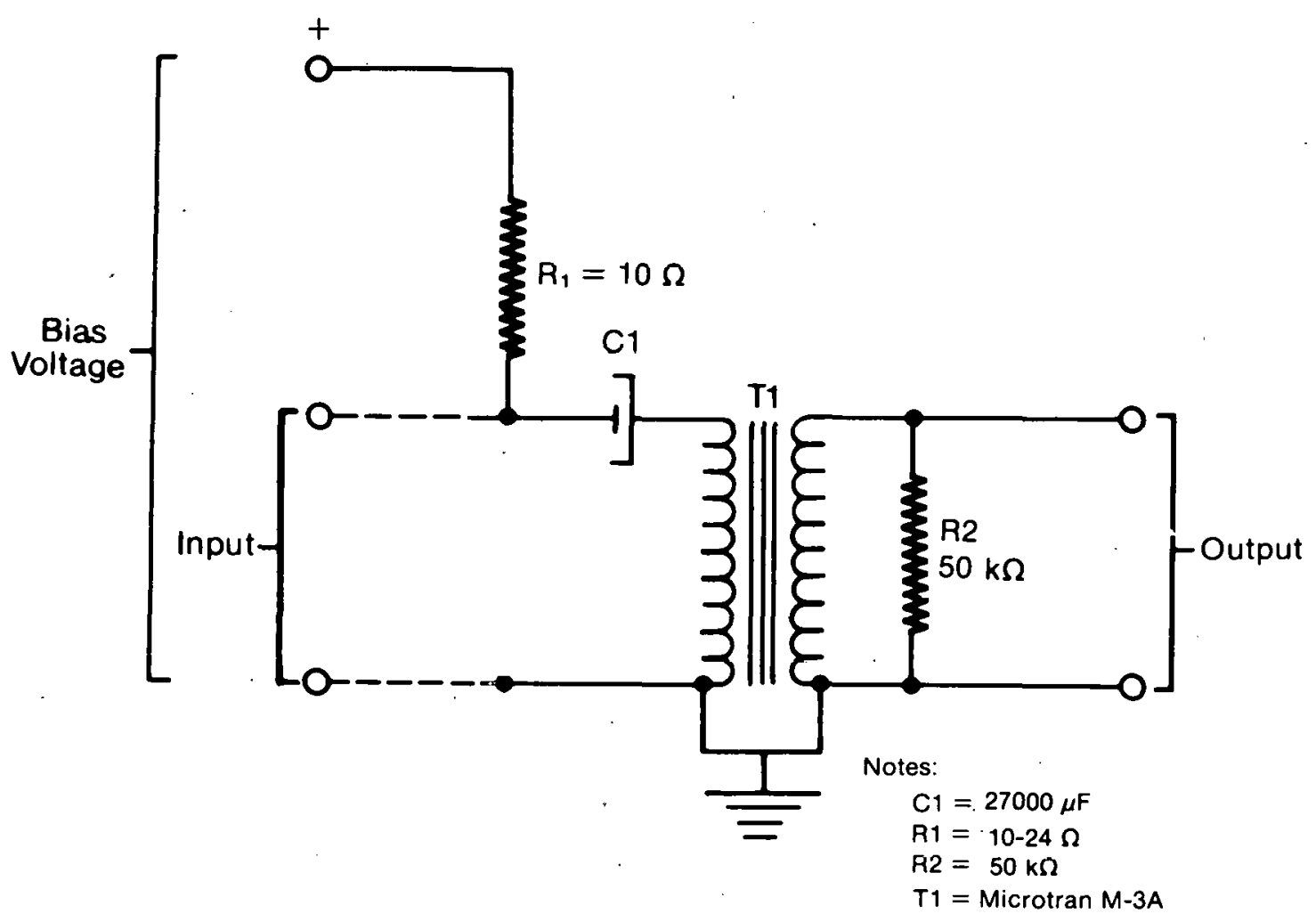

Figure 8. Impedance Matching Circuit 


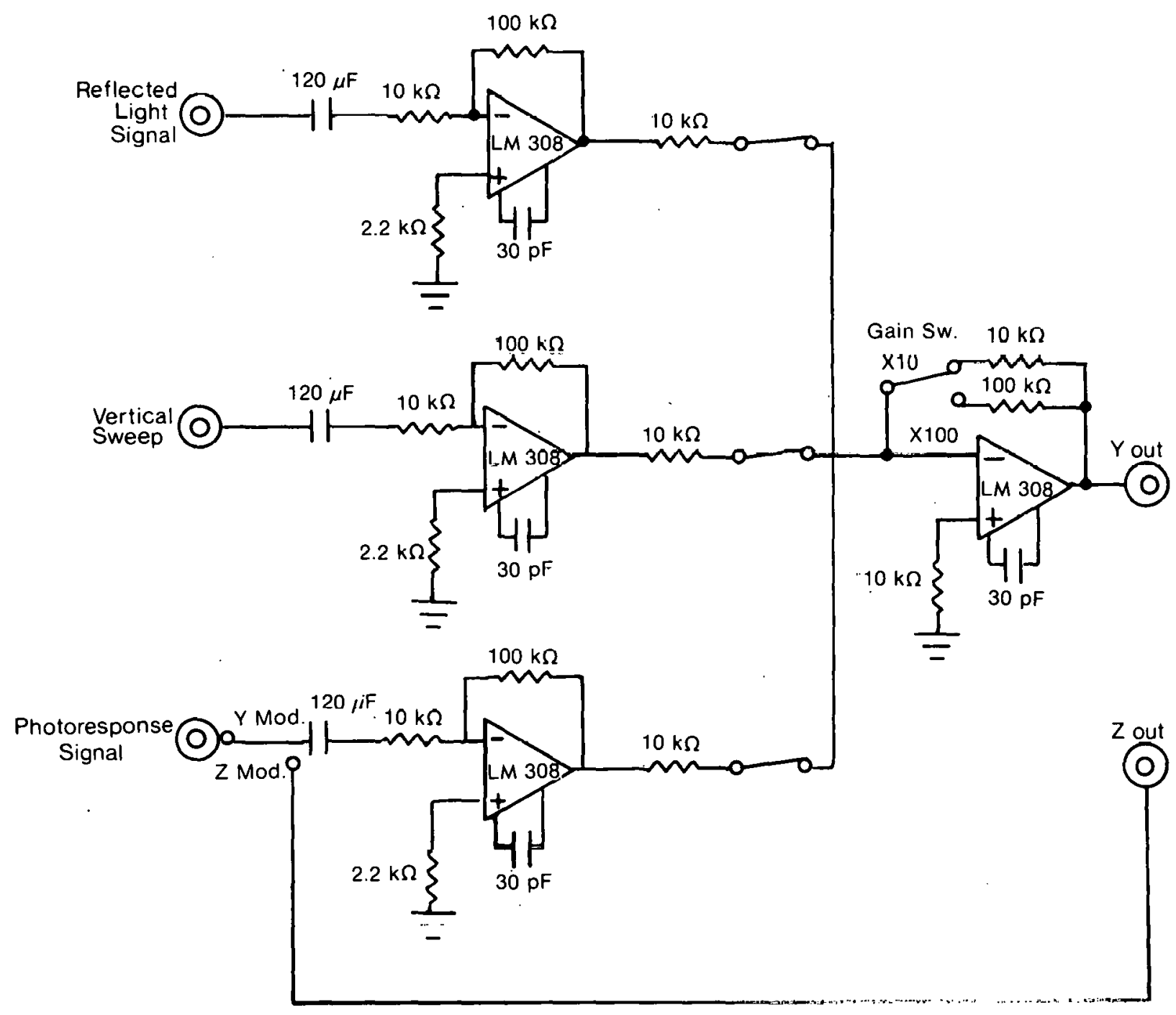

Figure 9. Signal Mixing Circuit 
superposition of current does not hold. Electrical biasing can also be used for most types of devices to emphasize electronic defects. The electrical biasing is provided by the bias power supply (14). A digital multimeter is used to monitor the bias power supply output current. 


\section{SECTION 3.0}

\section{FUTURE MODIFICATIONS}

The following modifications are expected to be added to the SERI LSS:

(1) Light bias. For proper light biasing a light source is required with (a) light intensities from 1 sun to 20 suns, (b) a reasonably uniform intensity across the area to be biased, and (c) spectral irradiance content resembling that of the sun. The high intensities are used to bias concentrator cells. An intensity uniformity of $\pm 10 \%$ across the cell is expected to suffice. Depending on the device, the light bias intensity will affect the laser response signal contrast across the cell to varying degrees. The spectral content primarily affects those materials for which the principle of superposition of current does not hold. A filtered ELH lamp of the required intensity should be adequate in this applicatinn.

The issue of light biasing is further divided into light biasing under low magnification conditions, where the sample area to be illuminated is larger yet easily accessible by a light source, and light biasing under high magnification oonditions, where the microscope objective is very close to the cell. The latter conditions require either a light ring that fits onto the objective or a series of light pipes entering from at least four different directions. The light ring is more uniform but also more expensive. The light pipes are currently used by NBS.

(2) Tilting temperature-controlled vacuum stage with micrometer-adjustable travel. The vacuum is required to hold down the sample and make firm electrical back contact. The temperature control $\left(20^{\circ}\right.$ to $\left.125^{\circ} \mathrm{C}\right)$ is for grain boundary phenomena studies. A 0 - to 3 -degree tilt will be used for optimizing the reflected light signal. The micrometer adjustments are required for fine positioning at high magnifications.

(3) Optics and support frame enclosure. To eliminate effeots from the mechanical vibrations of the environment, the entire optical portion of the LSS will be rigidly mounted on a vibration-isolated optical table.

(4) Laser light intensity control. With the more efficient test samples, the signal can easily become excessive even when bypassing the signal preamplifier. A circular neutral density filter in the light path will be used to odjust the light intunsity.

(5) Photomultiplier. The Ge diode in the reflected light detector will be replaced by a photomultiplier to increase significantly the sensitivity to the reflected light and diminish the time constant of the detector circuit. This has been done at NBS with the result that the reflected light images have much greater detail. Futhermore, the LSS could then be used for recombination radiation mapping.

(6) Quantitative characterization. It is anticipated that the LSS will be developed from essentially a qualitative instrument to a quantitative instrument. This will be realized either by converting the display information of the present system from analogue to digital or by building a second system that employs a fixed beam and moving stage for quantitative characterization. 


\begin{tabular}{|c|c|c|}
\hline $\begin{array}{l}\text { Document Control } \\
\text { Page }\end{array}$ & $\begin{array}{l}\text { 1. SERI Report No. } \\
\text { RR-612-733 }\end{array}$ & 3. Recipient's Accession No. \\
\hline \multirow{2}{*}{\multicolumn{2}{|c|}{$\begin{array}{l}\text { 4. Title and Subtitle } \\
\text { SERI Laser Scanner System }\end{array}$}} & $\begin{array}{l}\text { 5. Publication Date } \\
\text { October ' } 1980 . \\
\end{array}$ \\
\hline & & 6. \\
\hline \multicolumn{2}{|c|}{$\begin{array}{l}\text { 7. Author(s) } \\
\text { Richard J. Matsun; Theordore W. Cannon }\end{array}$} & 8. Performing Organization Rept. No. \\
\hline \multicolumn{2}{|c|}{ 9. Performing Organization Name and Address } & $\begin{array}{l}\text { 10. Project/Task/Work Unit No. } \\
3825.10\end{array}$ \\
\hline \multicolumn{2}{|c|}{$\begin{array}{l}\text { Solar Energy Research Institute } \\
1617 \text { Cole Boulevard } \\
\text { Golden, Colorado } 80401\end{array}$} & $\begin{array}{l}\text { 11. Contract (C) or Grant (G) No. } \\
\text { (C) }\end{array}$ \\
\hline \multirow{2}{*}{\multicolumn{2}{|c|}{ 12. Sponsoring Organization Name and Address }} & $\begin{array}{l}\text { 13. Type of Report \& Period Covered } \\
\text { Research Report }\end{array}$ \\
\hline & & 14. \\
\hline \multicolumn{3}{|l|}{ 15. Supplementary Notes } \\
\hline \multicolumn{3}{|c|}{$\begin{array}{l}\text { 16. Abstract (Limit: } 200 \text { words) } \\
\text { A Laser Scanner System (LSS) produces a photoresponse map and can be used for } \\
\text { the nondestructive detection of nonuniformities in the photoresponse of a semi- } \\
\text { conductor device. At SERI the photoresponse maps are used to identify solar } \\
\text { cell faults including microcracks, metallization breaks, regions of poor contact } \\
\text { between metallization and the underlying emitter surface, and variations in } \\
\text { emitter sheet resistance. The SERI LSS is patterned after the LSS unit docu- } \\
\text { mented in the NBS Special Publication } 400-24 \text { "A Laser Scanner for Semiconductor } \\
\text { Devices" by D. E. Sawyer and D. W. Berning. Assuming reader familiarity with } \\
\text { the above publication, the present report proceeds by specifying the modifi- } \\
\text { cations introduced by SERI with the intention that the two reports can be used } \\
\text { to reproduce the SERI LSS. This report reviews the optical and electronic } \\
\text { systems, briefly discussing the significant items of each. The most notable } \\
\text { difference between the two systems is the SERI substitution of commercially } \\
\text { available state-of-the-art modular electronics for the discreet component } \\
\text { circuitry used in the NBS LSS. }\end{array}$} \\
\hline \multicolumn{3}{|c|}{$\begin{array}{l}\text { 17. Document Analygis } \\
\text { a. Descriptors Solar Energy; Semiconductor Devices; Optical Systems; Lasers; Helium- } \\
\text { neon Lasers; Optical Scanners; Electronic Circuits; Solar Cells; } \\
\text { Diagrams; Nondestructive Testing; Lracks; Mlcruslructure } \\
\text { b. Identifiers/Open-Ended Terms }\end{array}$} \\
\hline \multicolumn{3}{|l|}{$\begin{array}{c}\text { c. UC Categories } \\
63\end{array}$} \\
\hline \multirow{2}{*}{\multicolumn{2}{|c|}{$\begin{array}{l}\text { 18. Availability Starement } \\
\text { National Technical Information Service } \\
\text { U.S. Department of Commerce } \\
5285 \text { Port.Royal Road } \\
\text { Springfield, VA } 22161\end{array}$}} & $\begin{array}{r}\text { 19. No. of Pages } \\
19\end{array}$ \\
\hline & & $\begin{array}{r}\text { 20. Price } \\
\end{array} \$ 4.00$ \\
\hline
\end{tabular}

